\title{
Experimental Investigation of Variation of Mass Flow Rate on the Performance of Parabolic Dish Collector with Nickel Chrome Coated Receiver
}

\author{
Atul A. Sagade \\ New Satara College of Engineering \& Management (Polytechnic), \\ Korti-Pandharpur, PIN-413304, Maharashtra, India ${ }^{1}$
}

\begin{abstract}
From Indian perspective there is a large potential available for low cost solar water heating systems. With described system we can fulfill needs of hot water in domestic as well as industrial sector. Concentrated solar collectors have high efficiency as compared to flat plate \& evacuated tube solar collectors. Therefore for water heating application, we can achieve high efficiency. Authors have used parabolic dish collector for water heating. This paper explains the effect of variation of mass flow rate on performance of parabolic dish collector with nickel chrome coated receiver. Design of solar parabolic dish collector consists of truncated cone shaped helical coiled receiver made up of copper at focal point. This prototype was evaluated for its performance during month of April \& May 2010 at Kolhapur, Maharashtra, India [Latitude: $16.42^{\circ}$ North, Longitude: $74.13^{\circ}$ West]
\end{abstract}

\section{Introduction}

The concentrated solar thermal energy system is designed and constructed with the conventional parabolic concentrator with the receiver, placed along the line between the center of the concentrator and the Sun. The receiver is coiled helically with specific design, so that all the solar rays concentrated at center without shadow. Manual tracking is used during evaluation stage. This allows for effective collecting and concentrating of the incoming solar irradiation. The concentrator receives approximately $1.064 \mathrm{~kW} / \mathrm{m} 2$ of global (Total) solar insolation (dependent upon time of year), which is concentrated and reflected to the receiver. By concentrating the incoming radiation from the sun on to the receiver, the operating temperature of the system increases significantly and subsequently increases the efficiency of the conversion. [15] There is a need of research on low cost parabolic dish solar water heater in view of

1. Life of solar water heating systems

2. Appropriate capacity for the end user

3. Low head systems for water heating

4. Conversion efficiencies

5. The floor space area availability for such solar water heating systems
6. Cost of conversion, installation and maintenance of such system.

7. Skills required for operation and maintenance

\section{Literature Survey}

Hussain Al-Madani studied a batch solar water heater in Bahrain consisting of an evacuated, cylindrical glass tube. Side-by-side testing of prototypes resulted in a maximum temperature difference between the inlet and outlet of the cylindrical batch system of $27.8^{\circ} \mathrm{C}$ with a maximum efficiency of $41.8 \%$.[7]

Tripanagnostopoulos and Souliotis experimented on optimizing an integrated storage-collector batch solar water heater that contained two cylindrical tanks and a compound parabolic concentrator made of aluminum mylar glazed with an iron oxide and black matte absorbing surface [1]

A simpler batch solar water heater has been investigated by Akuffo and Jackson in Ghana. The integrated storage-collector unit was a rectangular galvanized steel box with a total storage capacity of 90L. "Angle iron" was used to support the edges and prevent buckling and jute fiber was used for insulation. This design achieved a maximum temperature of $45^{\circ} \mathrm{C}$ by $4: 30 \mathrm{pm}$ and provided $30^{\circ} \mathrm{C}$ water at 5:30am the next day. Daily ambient peak temperatures exceeded $37^{\circ} \mathrm{C}$. [2]

Nahar studied a separated storage-collector system. Nahar found that this system can produce $60.6^{\circ} \mathrm{C}$ water at $4: 00 \mathrm{pm}$ and $51.6^{\circ} \mathrm{C}$ water the next morning. The overall efficiency of this system was determined to be $57 \%[4,5]$. Zerrouki et al. in studied a similar separated storage-collector system Algeria. The maximum temperature was observed to be $57^{\circ} \mathrm{C}$ starting from an initial temperature of $17^{\circ} \mathrm{C}$ at 7:00am. [6]

\section{Description of System Used}

System consists of a parabolic dish of $1.4 \mathrm{~m}$ diameter. It is made up of anodized aluminium mirrors \& supported with locally manufactured steel stand. At focus truncated cone shaped helical coil, made up of copper is fitted \& it is coated with nickel 
chrome. Inner \& outer diameters of hollow receiver coils are $5.0 \mathrm{~mm} \& 5.1 \mathrm{~mm}$ respectively. The spacing between two coils is $5 \mathrm{~mm} \&$ angle of helix is $5^{\circ}$. Inlet $\&$ outlet pipes made of high temperature \& pressure PVC are attached to coil. Inlet water flow is controlled by using inlet valve \& hot water at outlet is collected in insulated tank. Thermocouples used to measure the temperatures of inlet $\&$ outlet water and

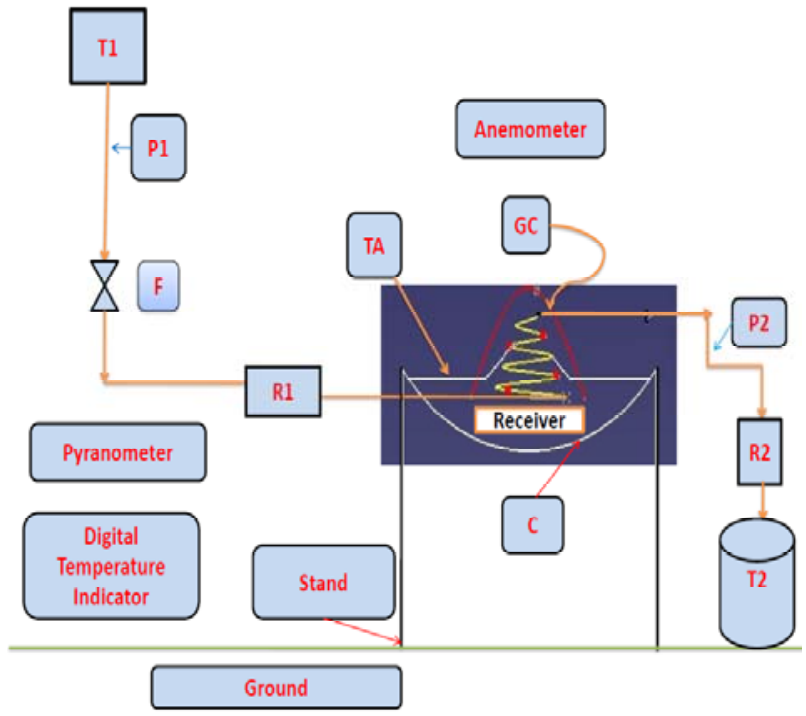

Figure 1. Schematic Diagram of Test Set up and Instrumentation receiver surface temperature. Wind speed has been measured by using anemometer \& solar radiation by using Pyranometer. This prototype was evaluated for its performance during month of April \& May 2010 under standard test conditions.

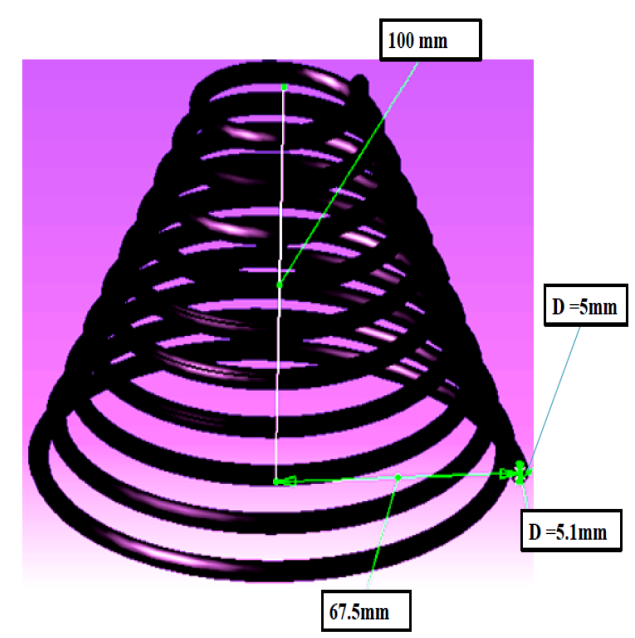

Figure 2. Receiver (with black Nickel chrome paint coating)

Table 1. Parameters of system used for experimentation

\begin{tabular}{|l|l|l|}
\hline Sr. no & Name of component & Dimension \\
\hline 1 & Diameter of Parabolic dish & $1.4 \mathrm{~m}$ \\
\hline 2 & Thickness of mirror of Parabolic dish & $2 \mathrm{~mm}$ \\
\hline 3 & Reflectivity of Parabolic dish & 0.86 \\
\hline 4 & Depth of Dish & $0.38 \mathrm{~m}$ \\
\hline 5 & Focal length of dish & $0.3223 \mathrm{~m}$ \\
\hline 6 & Surface area of parabolic dish collector & $1.9295 \mathrm{~m} 2$ \\
\hline 7 & Aperture area of parabolic dish collector & $1.54 \mathrm{~m} 2$ \\
\hline 8 & Diameter of receiver at bottom & $0.135 \mathrm{~m}$ \\
\hline 9 & Diameter of receiver at top & $0.095 \mathrm{~m}$ \\
\hline 10 & Mean Diameter of receiver & $0.115 \mathrm{~m} 2$ \\
\hline 11 & Surface area of receiver & $0.2357 \mathrm{~m} 2$ \\
\hline 12 & Effective length of receiver coil & $3.96 \mathrm{~m}$ \\
\hline 13 & Thermal conductivity of copper & $384(\mathrm{~W} / \mathrm{m} \mathrm{k})$ \\
\hline 14 & Density of copper & $8.9(\mathrm{gm} / \mathrm{cm} 3)$ \\
\hline 15 & Melting point of copper & $1083\left({ }^{\circ} \mathrm{C}\right)$ \\
\hline 16 & Specific gravity of copper & 8.9 \\
\hline 17 & Absorptivity-transmitivity product of copper & 0.7 \\
\hline 18 & Emissivity of copper & 0.725 \\
\hline 19 & Absorptivity-transmitivity product of coating & 0.94 \\
\hline 20 & Emissivity of coating & $0.10-0.14$ \\
\hline
\end{tabular}




\section{Experimental Procedure}

The schematic diagram of the experimental setup is shown in Figure.1. It consists of a cavity receiver supported by support stand. The receiver has kept vertically upright with respect to the horizontal. The cold water circulated in the receiver has been supplied from a water tank of 100 litre capacity. The working fluid has been circulated through the receiver tubes by gravity. A rotameter at inlet, measures the mass flow rate of cold water entering the receiver. The cold water has been circulated at constant inlet temperature through the receiver. The temperatures of the fluid in the tube at four locations (including the outlet) have been measured using K-type thermocouples. The flow has been kept constant for the complete period of an experimental run on a given day. The system has been operated under open loop condition as the water exiting from the receiver has been not circulated back to the inlet cold water supply tank. The hot water has stored in an insulated tank at the near the outlet. The wind speed measurements have been taken at a fixed location near the parabolic dish collector plane. The wind may be in the direction normal to the receiver $\&$ also the direction of the wind may be parallel to the receiver.

All the measuring instruments used in the experiments are calibrated. The working fluid has been cold water and on experiment days inlet temperatures varies between $23^{\circ} \mathrm{C}$ and $27^{\circ} \mathrm{C}$. For each test, the inlet fluid temperature has been measured using thermocouple. The working fluid will enter in and exit from the receiver as shown in Fig.1. The working fluid inlet has been at the bottom portion of the receiver and flows through the helically coiled receiver \& leaves receiver at the uppermost portion. This has been to ensure that the highest temperatures are at the top of the cavity receiver and lower temperatures near the concentrator. The flow rate of water has been kept constant at on given day of experiment.

The solar radiations, tube temperatures and the fluid temperatures are measured at intervals of half hour and the experiment has been continued till the solar radiation has been available at sufficient intensity. The thermal losses are estimated at steady state. Helical coil as shown in Figure. 2 representing the receiver with coating of black nickel chrome paint. For the experiments with black coated receiver, the region outside the cavity has been surrounded by a downward facing cylindrical glass enclosure.

Table 2. Experimental Measurements \& calculations at mass flow rate $\dot{\boldsymbol{m}}=\mathbf{0 . 0 0 7 6} \mathrm{kg} / \mathrm{s}$

\begin{tabular}{|c|c|c|c|c|c|c|c|c|c|c|c|}
\hline $\begin{array}{c}\text { Measured } \\
\text { solar } \\
\text { radiation } \\
\text { on } \\
\text { Horizontal } \\
\text { surface } \\
\left(\mathrm{W} / \mathrm{m}^{2}\right)\end{array}$ & $\begin{array}{c}\text { beam } \\
\text { radiation } \\
\text { on } \\
\text { collector } \\
\text { aperture } \\
\text { area } \\
\left(\mathbf{W} / \mathbf{m}^{2}\right) \\
\end{array}$ & $\begin{array}{l}\text { Tin } \\
\left({ }^{\circ} \mathbf{C}\right)\end{array}$ & $\begin{array}{l}\text { Tout } \\
\left({ }^{\circ} \mathbf{C}\right)\end{array}$ & $\begin{array}{c}\text { Tamb } \\
\left({ }^{\circ} \mathrm{C}\right)\end{array}$ & $\begin{array}{c}\text { Average } \\
\text { Receiver } \\
\text { Temp. } \\
(\mathbf{T r}) \\
\left({ }^{\circ} \mathbf{C}\right)\end{array}$ & $\begin{array}{l}\text { Wind } \\
\text { speed } \\
\text { Avg } \\
\text { m/s }\end{array}$ & $\begin{array}{c}\text { Optical } \\
\text { Energy } \\
\text { Captured } \\
\text { by } \\
\text { Receiver } \\
\text { (W) }\end{array}$ & $\begin{array}{c}\text { Overall } \\
\text { heat loss } \\
\text { coefficient } \\
\left(\mathrm{W} / \mathbf{m}^{2 \circ} \mathbf{C}\right)\end{array}$ & $\begin{array}{l}\text { Total } \\
\text { heat } \\
\text { Loss } \\
\text { (W) }\end{array}$ & $\begin{array}{c}\text { Useful } \\
\text { heat } \\
\text { gain by } \\
\text { Water } \\
\text { (W) }\end{array}$ & $\begin{array}{c}\text { Collector } \\
\text { Efficiency } \\
(\%)\end{array}$ \\
\hline 590 & 510 & 26 & 45 & 31 & 66.75 & 3.80 & 606.94 & 7.87 & 66.28 & 540.66 & 68.73 \\
\hline 630 & 614 & 26 & 49 & 31 & 73.00 & 4.65 & 730.28 & 8.97 & 88.75 & 641.53 & 67.78 \\
\hline 660 & 671 & 27 & 52 & 32 & 82.00 & 4.03 & 797.65 & 8.18 & 96.37 & 701.29 & 67.84 \\
\hline 700 & 707 & 28 & 53 & 32 & 84.25 & 5.38 & 841.00 & 10.13 & 124.80 & 716.20 & 65.71 \\
\hline 770 & 571 & 29 & 48 & 32 & 85.75 & 5.13 & 679.48 & 10.16 & 128.74 & 550.74 & 62.54 \\
\hline 830 & 804 & 30 & 57 & 32 & 95.75 & 4.43 & 955.67 & 8.53 & 128.21 & 827.46 & 66.81 \\
\hline 910 & 831 & 30 & 57 & 32 & 113.25 & 5.63 & 988.58 & 10.91 & 208.93 & 779.65 & 60.85 \\
\hline 990 & 868 & 31 & 57 & 33 & 127.00 & 6.25 & 1032.21 & 12.48 & 276.42 & 755.79 & 56.50 \\
\hline 930 & 858 & 31 & 57 & 32 & 120.50 & 6.60 & 1020.59 & 12.69 & 264.78 & 755.81 & 57.14 \\
\hline 630 & 828 & 32 & 59 & 32 & 98.75 & 5.80 & 984.22 & 10.49 & 165.06 & 819.16 & 64.22 \\
\hline 670 & 785 & 32 & 57 & 31 & 102.25 & 6.10 & 933.49 & 11.08 & 186.07 & 747.42 & 61.78 \\
\hline 580 & 607 & 33 & 53 & 31 & 79.00 & 4.98 & 722.38 & 9.11 & 103.11 & 619.28 & 66.15 \\
\hline 520 & 522 & 33 & 50 & 31 & 74.25 & 5.23 & 621.40 & 9.58 & 97.63 & 523.77 & 65.04 \\
\hline
\end{tabular}


Table 3. Experimental Measurements \& calculations at mass flow rate $\dot{\mathbf{m}}=\mathbf{0 . 0 0 5 6} \mathrm{kg} / \mathrm{s}$

While measurements with mass flow rate of $0.0056 \mathrm{Kg} / \mathrm{s}$ receiver is covered with cylindrical glass cover of thickness $2 \mathrm{~mm}$. This helps to reduce heat losses from receiver.

\begin{tabular}{|c|c|c|c|c|c|c|c|c|c|c|c|}
\hline $\begin{array}{c}\text { Measured } \\
\text { solar } \\
\text { radiation } \\
\text { on } \\
\text { Horizontal } \\
\text { surface } \\
\left(\mathrm{W} / \mathrm{m}^{2}\right) \\
\end{array}$ & $\begin{array}{c}\text { beam } \\
\text { radiation } \\
\text { on } \\
\text { collector } \\
\text { aperture } \\
\text { area }\end{array}$ & $\begin{array}{l}\text { Tin } \\
\left({ }^{\circ} \mathrm{C}\right)\end{array}$ & $\begin{array}{l}\text { Tout } \\
\left({ }^{\circ} \mathrm{C}\right)\end{array}$ & $\begin{array}{c}\text { Tamb } \\
\left({ }^{\circ} \mathbf{C}\right)\end{array}$ & $\begin{array}{c}\text { Average } \\
\text { Receiver } \\
\text { Temp. } \\
(\mathrm{Tr})\left({ }^{\circ} \mathrm{C}\right)\end{array}$ & $\begin{array}{c}\text { Wind } \\
\text { speed } \\
\text { Avg } \\
\text { m/s }\end{array}$ & $\begin{array}{c}\text { Optical } \\
\text { Energy } \\
\text { Captured } \\
\text { by } \\
\text { Receiver } \\
\text { (W) }\end{array}$ & $\begin{array}{c}\text { Overall } \\
\text { heat loss } \\
\text { coefficient } \\
\left(\mathrm{W} / \mathbf{m}^{2 \circ} \mathbf{C}\right)\end{array}$ & $\begin{array}{l}\text { Total } \\
\text { heat } \\
\text { Loss } \\
\text { (W) }\end{array}$ & $\begin{array}{c}\text { Useful } \\
\text { heat } \\
\text { gain by } \\
\text { Water } \\
\text { (W) }\end{array}$ & $\begin{array}{c}\text { Collector } \\
\text { Efficiency } \\
(\%)\end{array}$ \\
\hline 500 & 400 & 26 & 42 & 31 & 56 & 2.725 & 475.35 & 6.23 & 36.69 & 438.66 & 71.20 \\
\hline 680 & 567 & 27 & 51 & 31 & 76 & 3.7 & 674.30 & 7.47 & 79.28 & 595.02 & 68.09 \\
\hline 730 & 610 & 28 & 54 & 32 & 80.75 & 4.25 & 725.42 & 8.24 & 94.69 & 630.73 & 67.09 \\
\hline 610 & 497 & 29 & 50 & 32 & 65.75 & 5.175 & 590.40 & 9.33 & 74.25 & 516.15 & 67.46 \\
\hline 830 & 690 & 30 & 56 & 32 & 104 & 5.525 & 819.35 & 10.64 & 180.63 & 638.72 & 60.15 \\
\hline 970 & 805 & 30 & 64 & 33 & 114.25 & 3.8 & 956.64 & 7.89 & 151.16 & 805.48 & 64.97 \\
\hline 850 & 695 & 31 & 60 & 33 & 107 & 4.275 & 825.32 & 8.57 & 149.49 & 675.83 & 63.18 \\
\hline 490 & 383 & 31 & 48 & 33 & 63.25 & 4.25 & 455.69 & 7.94 & 56.61 & 399.08 & 67.58 \\
\hline 530 & 422 & 32 & 50 & 33 & 60.25 & 5.2 & 500.98 & 9.04 & 58.07 & 442.91 & 68.22 \\
\hline 570 & 461 & 32 & 51 & 34 & 62.25 & 3.875 & 547.26 & 7.17 & 47.77 & 499.49 & 70.43 \\
\hline 810 & 684 & 33 & 61 & 33 & 67 & 6.025 & 812.97 & 9.94 & 79.67 & 733.30 & 69.60 \\
\hline 850 & 726 & 33 & 64 & 33 & 73.25 & 5.2 & 862.62 & 8.63 & 81.90 & 780.72 & 69.83 \\
\hline 810 & 692 & 32 & 64 & 33 & 71 & 4.275 & 821.91 & 7.20 & 64.50 & 757.41 & 71.11 \\
\hline 730 & 622 & 32 & 63 & 32 & 67.25 & 3.1 & 738.68 & 5.41 & 44.94 & 693.73 & 72.47 \\
\hline 670 & 520 & 31 & 57 & 32 & 62 & 4.475 & 618.26 & 7.52 & 53.16 & 565.10 & 70.53 \\
\hline
\end{tabular}

\section{Calculations}

\subsection{Terrestrial solar radiation:}

Ground level radiation can be estimated using Hottel's clear sky model for urban visibility $5 \mathrm{~km}$ at Kolhapur

Altitude of Kolhapur $(\mathrm{A})=563 \mathrm{~m}$

$$
\text { (A) }=0.563 \mathrm{~km} \text {. }
$$

Constants $a_{0}, a_{1}, K$ in Hottel's model can be calculated as follows

$\mathrm{a}_{\mathrm{o}}=0.2538-0.0063(6-\mathrm{A})^{2}$

$\mathrm{a}_{1}=0.7678+0.0010(6.5-\mathrm{A})^{2}$

$\mathrm{K}=0.249+0.081(2.5-\mathrm{A})^{2}$

Instantaneous direct radiation $\left(\mathrm{I}_{\mathrm{bn}}\right)$ on horizontal surface at ground level is given by [12]

$\mathrm{I}_{\mathrm{bn}}=\mathrm{Io}\left(\mathrm{ao}+\mathrm{a} 1 \times \mathrm{e}-\frac{\mathrm{K}}{\cos \theta \mathrm{z}}\right)$------Eq.1

From instantaneous direct radiation (IBN) on horizontal surface, direct radiation on collector surface has been estimated.

\subsection{Geometric Concentration Ratio for Designed Collector}

Geometric concentration ratio for designed collector is given by [12]

$\mathrm{CR}_{\text {geo }}=\frac{\text { Aconc. }}{\mathrm{Ar}}$
Useful heat gain by water is given by [12]

$\mathrm{Q}_{\text {useful }}=\mathrm{Q}_{\text {opt }}-\mathrm{Q}_{\text {loss }}(\mathrm{W})---------------------------E q .3$

Where,

$\mathrm{Q}_{\text {opt }}=$ optical radiation trapped receiver $(\mathrm{W})$

$\mathrm{Ql}_{\mathrm{oss}}=$ rate of hest loss from receiver $(\mathrm{W})$

\subsection{Calculation of Heat Losses from the Receiver}

Thermal losses from solar open cavity receivers include convective and radiative losses to air.

For focal plane i.e. cavity receiver overall heat loss is given by [12]

$\mathrm{Q}_{\text {loss }}=\mathrm{Ar} \times \mathrm{U}_{1} \times(\mathrm{Tr}-\mathrm{Ta})(\mathrm{W})----------------E q .4$

Where

$\mathrm{Tr}=$ Average receiver temp $\left({ }^{\circ} \mathrm{C}\right)$

$\mathrm{Ta}=$ Temp of air surrounding a receiver $\left({ }^{\circ} \mathrm{C}\right)$

$\mathrm{U}_{1}=$ Overall heat loss coefficient

To estimate natural convective heat loss, following correlation developed by Kedare et.al is used. [11]

$\mathrm{Nu}=0.21 \mathrm{Gr} 1 / 3(1+\mathrm{Cos} \theta \mathrm{r}) 3.2(\mathrm{Tm} / \mathrm{Ta})^{-1.5}---\mathrm{Eq} .5$

Where 
$\theta \mathrm{r}=$ receiver inclination angle $=90^{\circ}$

$\mathrm{Gr}=$ Grashof's number for natural convection

$\mathrm{Tm}=$ mean temperature of water in receiver coils at natural convection

Forced convection loss coefficient is given by eqn. This equation is developed by

Ma $[9,16]$

$\mathrm{h}_{\text {conv.forced }}=\mathrm{f}(\theta \mathrm{r}) \mathrm{v} 1.401\left(\mathrm{~W} / \mathrm{m} 2{ }^{\circ} \mathrm{C}\right)$---------Eq.6

Overall heat loss coefficient $\left(\mathrm{U}_{1}\right)$ is given by [12]

$\mathrm{U}_{1}=\left[\frac{1}{[\text { hconv.total +hrad }]}\right]^{-1}\left(\mathrm{~W} / \mathrm{m}^{2}{ }^{\circ} \mathrm{C}\right)$------------Eq.7

\section{Results and Discussion}

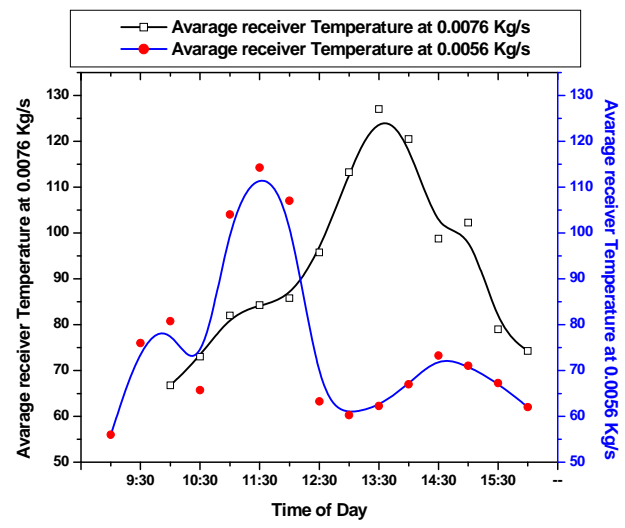

\section{Figure 3. Variation of average receiver temperatures throughout the day}

Fig. 3 shows Variation of average receiver temperatures throughout the day. It has been observed that average receiver temperature is affected by solar radiation \& wind velocity at instant. Receiver temperature increases in afternoon as solar radiation increases. With decreased flow rate $(0.0056 \mathrm{Kg} / \mathrm{s})$ of water \& receiver covered with glass cover, receiver temperature must increase as compared to higher flow rate $(0.0076 \mathrm{Kg} / \mathrm{s})$ \& no glass cover on receiver. But it has been observed that decreased solar radiation does not allow receiver temperature to increase as expected. Average receiver temperatures of $92^{\circ} \mathrm{C} \& 75^{\circ} \mathrm{C}$ have been achieved with flow rates $0.0076 \mathrm{Kg} / \mathrm{s} \& 0.0056 \mathrm{Kg} / \mathrm{s}$ respectively. It has been found that there is decrease of $18 \%$ in receiver temperature with reduced flow rate. Due to wind velocity at instant as flow rate of water reduces heat loss from receiver surface increases.
Where,

Radiative heat transfer coefficient $\left(\mathrm{h}_{\mathrm{rad}}\right)$ is given by [12]

$\mathrm{h}_{\mathrm{rad}}=\frac{\varepsilon \sigma\left(\mathrm{Tr}-\mathrm{avg}^{4}-\mathrm{Ta}^{4}\right)}{\mathrm{Tr}-\mathrm{avg}-\mathrm{Ta}}\left(\mathrm{W} / \mathrm{m}^{2}{ }^{\circ} \mathrm{C}\right)$-----------Eq.8

Total convective heat loss coefficient $\left(\mathrm{h}_{\text {conv.total }}\right)$ is given by $[12,16]$

$\mathrm{h}_{\text {conv.total }}=\mathrm{h}_{\text {conv.natural }}+\mathrm{h}_{\text {conv.forced }}\left(\mathrm{W} / \mathrm{m}^{2}{ }^{\circ} \mathrm{C}\right)$---Eq.9

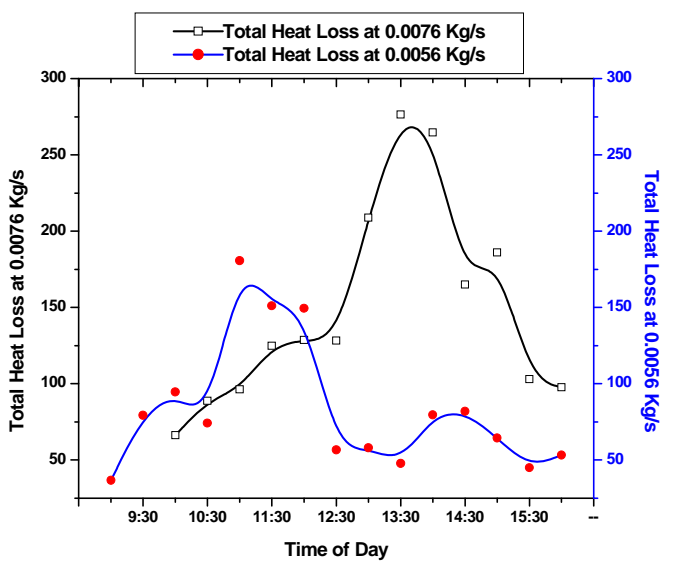

Figure 4. Variation of total heat losses throughout the day

Fig. 4 indicates Variation of total heat losses throughout the day. As explained earlier, an average receiver temperature has been affected by solar radiation \& wind velocity at instant similarly total heat losses at instant also affected by solar radiation \& wind velocity. With decreased flow rate $(0.0056 \mathrm{Kg} / \mathrm{s})$ of water \& glass cover, it has been found that heat loss also get reduced as compared to higher flow rate $(0.0076 \mathrm{Kg} / \mathrm{s})$ \& no glass cover on receiver. Average heat loss of $148 \mathrm{~W}$ $\& 83 \mathrm{~W}$ has been achieved with flow rates 0.0076 $\mathrm{Kg} / \mathrm{s} \& 0.0056 \mathrm{Kg} / \mathrm{s}$ respectively. It has been found that there is decrease of $43 \%$ in average heat loss when receiver is covered with glass cover. 


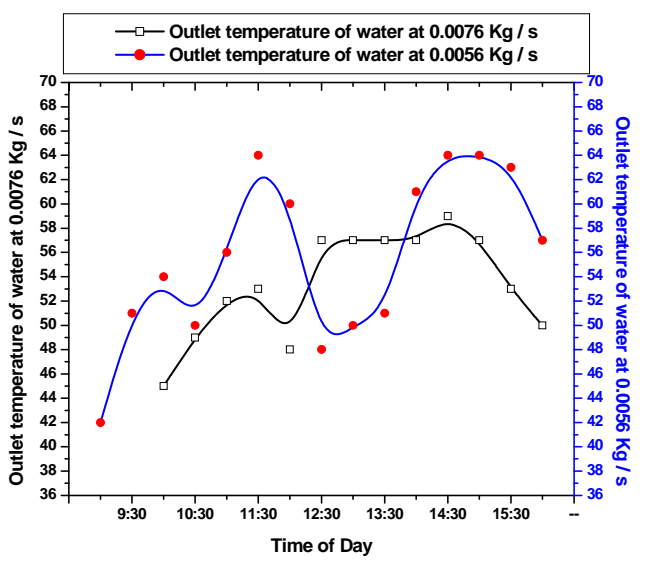

Figure 5. Variation of outlet temperatures of water throughout the day

From Fig. 5 it has been clear that, with reduced flow rate of water, the temperature of water coming out of receiver get increased as compared to higher flow rate. As receiver temperature increases, outlet water temperature also increases. As compared to flow rate of $0.0076 \mathrm{Kg} / \mathrm{s}$, there is average rise of 4 $\%$ in outlet water temperature of water with flow rate of $0.0056 \mathrm{Kg} / \mathrm{s} \&$ receiver covered with glass.

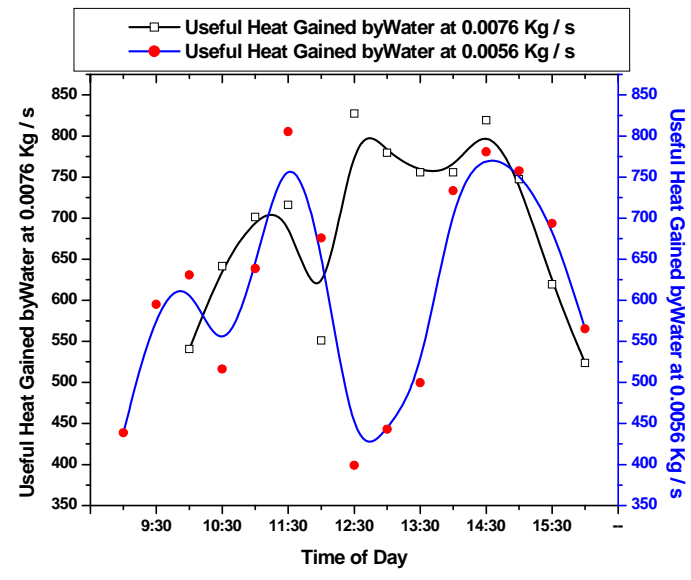

Figure 6. Variation of useful heat gained by water throughout the day

Fig. 6 shows Variation of useful heat gained by water throughout the day. Useful heat gained by water depends on solar radiation, receiver temperature \& wind velocity at instant. From Fig. 6 , it has been clear that water gained $11 \%$ more heat at flow rate of $0.0076 \mathrm{~kg} / \mathrm{s}$. but when flow rate has reduced to $0.0056 \mathrm{~kg} / \mathrm{s} \&$ receiver covered with glass, rate of heat loss from receiver get reduced. Also there is increase in outlet water temperature \& system performance.

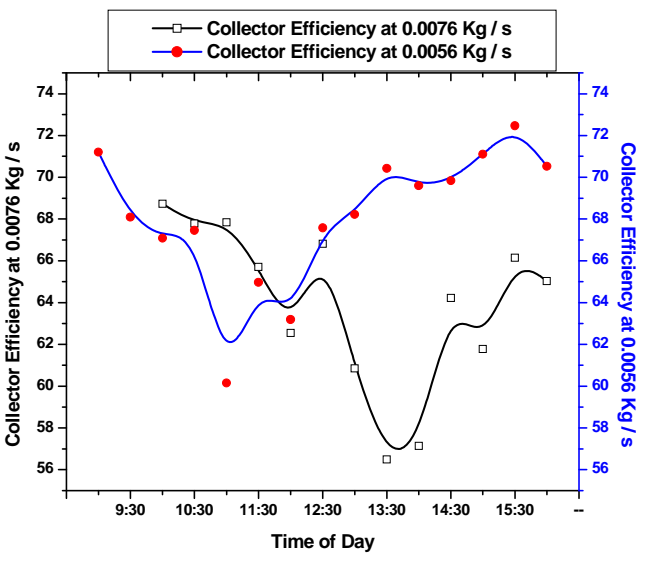
Figure 7. Variation of Collector Efficiencies
throughout the Day

Collector efficiency is again a function of parameters such as solar radiation, surface reflectance, receiver absorptance, atmospheric conditions, \& wind velocity. Fig. 7 shows variation of collector efficiencies throughout the day. It has been observed that there is rise of $4.19 \%$ in efficiency of collector with flow rate of $0.0076 \mathrm{~kg} / \mathrm{s}$ and receiver covered with glass.

\section{Conclusion}

An experimental and numerical study of parabolic solar Dish collector water heater with coated and non coated receiver has been conducted under Kolhapur climatic conditions. General comparison between the parabolic solar dish collector water heater and common models such as flat plate and evacuated tube collectors demonstrated that parabolic solar dish collector water heater is a good alternative for flat plate and evacuated tube water heaters and could be applied effectively. Therefore, the developed model can be considered for designing commercial parabolic solar dish collector water heater. Proposed system is aimed at saving conventional energy sources and environment too. Such objectives are important parts towards the development of self-sufficient sustainable homes in rural as well as urban areas of India. When receiver is covered with glass cover \& flow rate of water is reduced, system performance gets enhanced. Measure findings from experimentation have been listed.

1. There is rise of $4.19 \%$ in efficiency of collector with flow rate of $0.0076 \mathrm{~kg} / \mathrm{s} \&$ receiver covered with glass.

2. There is average rise of $4 \%$ in outlet water temperature of water with flow rate of $0.0056 \mathrm{Kg} / \mathrm{s}$ \& receiver covered with glass. 
3. Heat losses are also reduced as compared to higher flow rate $(0.0076 \mathrm{Kg} / \mathrm{s}) \&$ no glass cover on receiver. There is decrease of $43 \%$ in average heat loss when receiver is covered with glass cover

4. There is decrease of $18 \%$ in receiver temperature with reduced flow rate.

\section{References}

[1] Tripanagnostopoulos, Y., and M. Souliotis." ICS solar systems with two water tanks." Renewable Energy, (Dec.2006) Vol.31: Issue no. 15 , pp. $1698-1717$

[2] Akuffo, F.O., and E.A. Jackson. "Simulation studies on a compact solar water heater in the tropics." Solar and Wind Technology, (1998) Vol 5 , issue no6, pp.229-237

[3] Asif, M. and T. Muneer. "Life cycle assessment of built-in-storage solar water heaters in Pakistan." Building Service Engineering Research and Technology, (2006), Vol 27, pp.63-69

[4] Nahar, N.M. "Year round performance and potential of a natural circulation type of solar water heater in India." Energy and Buildings, (March 2003) Vol. 35, Issue no. 3, pp.239-247.

[5] Nahar, N.M. "Capital cost and economic viability of thermosyphonic solar water heaters manufactured from alternate materials in India." Renewable Energy, (Aug. 2002), Vol. 26, Issue no.04, pp. 623-635.

[6] Zerrouki, A. A. Boumedien, and K. Bouhadef. "The natural circulation solar water heater model with linear temperature distribution." Renewable Energy, (Aug.2002), Vol. 26, Issue no.04, pp.549559

[7] Al-Madani, Hussain. "The performance of a cylindrical solar water heater." Renewable Energy, (Dec.2006), Vol. 31, Issue no.15, pp.1751-1763
[8] H. Schweiger, J. Farinha Mendes, Ma. J. Carvalho,K. Hennecke and D. Krüger "Solar Heat for Industrial Processes", Advances in solar energy, (2007), vol.17, issue no. pp. 216-260

[9] Gordon, J. M. and Rabl, A. 'Design, analysis and optimisation of solar industrial process heat plants without storage', Solar Energy, (1982), Vol. 28, no 6, pp 519-530.

[10] Rabl,A. 'Comparison of solar concentrators', Solar Energy, no 18, pp93

[11]M. Prakash, S.B. Kedare, J.K. Nayak, "Investigations on heat losses from a solar cavity receiver ", Solar Energy, (Dec. 2009) Vol. 83, Issue no. 12 , pp.157-170.

[12]J. Duffie and W. Beckman, "Solar Engineering of Thermal Processes" John Wiley and Sons, Inc., New York (2006).

[13]Report by: Graham L. Morrison, "Developments in solar water heating" School of Mechanical and Manufacturing Engineering, New South Wales University, Australia.

[14] Report by: Simon Furbo, "Present and future SDHW systems technology" Technical University of Denmark.

[15] MSc Thesis of Mechanical Engg. Dept "High performance in low-flow solar domestic hot water systems", University of Wisconsin-Madison. (1997).

[16]A Master of Science (Mechanical Engineering) thesis of Paul R. Fraser "Stirling Dish System Performance Prediction Model" university of wisconsin-madison. (2008).

[17] Draft test procedure for "thermo siphon-type domestic solar hot water systems "developed by MNRE and BIS, (June 2009).

[18] Draft test procedure for "solar cooker paraboloid concentrator type "developed by MNRE and BIS, (August 2006). 